Copyright (C) 2021 by Cherkas Global University

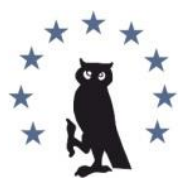

Published in the USA

Media Education (Mediaobrazovanie)

Has been issued since 2005

ISSN 1994-4160

E-ISSN 2729-8132

2021. 17(4): 612-622

DOI: $10.13187 / \mathrm{me} .2021 .4 .612$

https://me.cherkasgu.press

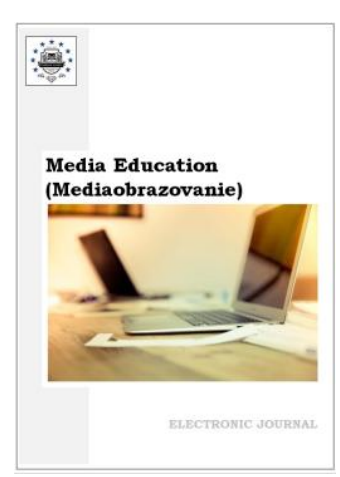

\title{
Media Education Model Aimed at Efficient Development of Audience's Skills to Reasonably Confront the False (or Partially False) Information, Contained in Anti-Russian Ukrainian Internet Communication Resources
}

\author{
Alexander Fedorov a , *, Anastasia Levitskaya ${ }^{\mathrm{b}}$ \\ a Rostov State University of Economics, Russian Federation \\ b Taganrog Institute of Management and Economics, Russian Federation
}

\begin{abstract}
The theoretical media-educational model developed by the authors of the article, aimed at the effective development of the audience's ability to reasonably counter the false (or partially false) information contained in the anti-Russian Internet communication sources from Ukraine (taking into account the ability to analyze the political, ideological, economic and other motives that lead to anti-Russian propaganda in Ukrainian media educational Internet communication portals, websites) consists of the following main structural building blocks (units):

Unit 1. Technology of development of audience's skills to reasonably confront false (or partially false) information contained in anti-Russian Ukrainian Internet communication sources (knowledge of media communication processes, propaganda influences and typology of false (or partially false) information; knowledge of basic techniques of analysis of Internet communication sources (including fact checking, political, ideological, economic and other motives conditioning anti-Russian propaganda in Ukrainian (media education) Internet communication portals, websites; skills to apply this knowledge in the process of the analysis of various web resources, containing anti-Russian propaganda.

Unit 2. Anti-propaganda Internet communications competence of the individual (information competence in the field of Internet communications and countering propaganda influences; analytical competence in the field of Internet communications related to detecting propaganda and/or fake messages).

Unit 3: The main indicators of anti-propaganda Internet communication competence of an individual (high level (a wide range of knowledge in the field of Internet communication, types and technologies of media influences, propaganda; types and technologies of media information analysis); medium level (limited knowledge in the field of Internet communication, types and technologies of media influences, propaganda; types and technologies of media information analysis); low level (no knowledge (or minimal knowledge) of these (see above).

Unit 4: Creative application of knowledge about media communication processes, propaganda influences and the typology of false (or partially false) information and analytical skills in this area (including the ability to independently apply knowledge about media communication processes, propaganda influences and the typology of false (or partially false) information and analytical skills in this area in new conditions and using new samples).
\end{abstract}

Keywords: media literacy, media education, media manipulation, propaganda, fake, Ukraine, internet.

\footnotetext{
* Corresponding author

E-mail addresses: 1954alex@mail.ru (A. Fedorov), a.levitskaya@tmei.ru (A. Levitskaya)
} 


\section{Introduction}

In our article "Theoretical model and technology of anti-Russian propaganda in Internet communications of modern Ukraine within the framework of various student groups' media education" (Fedorov, Levitskaya, 2021) we have specified and analyzed contemporary Ukrainian media sources of media education (Bakka et al., 2016; Cherepovska, 2010; 2017; Collection..., 2015; 2017; 2020; Filonenko, 2020; Ivanov et al, 2016; Kharitonyuk, 2020; Koropatnyk, 2015; 2017; 2020; Lazorenko, 2020; Media..., 2021; Naidenova et al., 2018; Naidenova and Dyatel, 2020; Pocheptsov, 2015; 2016; 2017; Vlasyuk et al., 2019; Yuksel, 2020; Zental, 2020; Zorya et al, 2021, etc.) and have synthesized a theoretical model in this direction (in some or other variations used by Ukrainian media educators and media culture figures), which consists of the following units:

- a unit of introduction to the problem, including clichéd propaganda phrases about Russian aggression and propaganda, and the need to emphasize the counter-propaganda function of media education;

- a unit of "appeal to authority" (a brief review of literature on media education, media manipulation, information wars with an emphasis on the political positions of the European Union, the United States, the concepts of Western scientists in the field of media culture, media education and political science, UNESCO documents, etc.). Meanwhile, anti-Russian phrases are carefully chosen from a wide range of scientific literature;

- a unit of examples of Russian media propaganda (often from marginal sources and with selective manipulation and emotional interpretation);

- a unit containing the main methods of analyzing Russian media sources (often selectively manipulative);

- a unit of conclusions of an anti-Russian orientation, often in no way arising from the previously cited media examples (Fedorov, Levitskaya, 2021).

In this article, based on generalization, classification, and theoretical modeling, we present the media education model aimed at the effective development of audience's skills to reasonably counteract false (or partially false) information contained in anti-Russian Ukrainian Internet communication sources related to media literacy, media pedagogy, media competence, information propaganda, and counterpropaganda.

\section{Materials and methods}

For this study, we 1) collected data on the parameters of the state of the research's subject in various sources in order to identify and actualize its main features, reflecting its essence and the most characteristic forms of its relations with the environment; 2) recorded the subject's features, having derived its indicators by analyzing the model of the subject under study and situations where such indicators are manifested. Therefore the following methods were used: data collection, generalization and classification, theoretical modeling.

\section{Discussion}

The problems of propaganda and misinformation that must be confronted have been addressed in recent years in a considerable body of literature from around the world (Albright, 2017; Aldwairi, Alwahedi, 2018; Azzimonti, Fernandes, 2018; Bakir, McStay, 2018; Balmas, 2012; Bean, 2017; Berghel, 2017; Bertin et al, 2018; Bharali, Goswami, 2018; Bradshaw, Howard, 2018; Marwick, 2018; Mihailidis,Viotty, 2017; Waldrop, 2017). In particular, fake news on political topics has been studied repeatedly (Balmas, 2012; Dentith, 2017; Farkas,Schou, 2018; Figueira,Oliveira, 2017; Fletcher et al., 2018; Fletcher,Nielsen, 2017; Quandt et al, 2019; Vargo et al., 2018, etc.) and patterns for detecting fake media information (Conroy et al., 2015; Derakhshan Wardle, 2017; Gahirwal et al., 2018; Goering, Thomas, 2018; Janze, Risius, 2017; Ruchansky et al., 2017).

Many scholars hold the view that "fact-checking sites and media literacy campaigns presume that people will not share news if they know it is inaccurate, painting users as cultural dupes at the mercy of media elites. But this is simply a newer form of the "magic bullet" media effects model popular in the first half of the 2oth century. This theory conceptualized media "messages as magic bullets capable of mesmerizing listeners who passively received and responded to communicative stimuli in an essentially uniform manner." In contrast, active audience approaches require understanding how and why people make meaning from media, viewing media use within a particular sociocultural context” (Marwick, 2018: 477). 
As some researchers maintain, "media literacy is the only way to detect fake news and fake photographs" and disinformation (Bharali, Goswami, 2018: 128; Mihailidis, Viotty, 2017).

However "no one imagines that media literacy will be easy to foster, however. It's one thing to learn how the media works and how to watch out for all the standard misinformation tricks... But it's quite another to master ... emotional skepticism, which urges users to slow down and check things before sharing them" (Waldrop, 2017: 12634).

Within the framework of the chosen theme, it is worth noting that more than often, the articles by Western media scholars focused on the problem of propaganda and fake media information, highlight Russian media influence (Lipman, 2009) and accuse leading Russian media channels (including Russian drama/comedy TV series) of media manipulation and one-sided interpretation of information (Giles, 2016; Khaldarova, Pantti, 2016; Murrok et al, 2018; NATO, 2016; Saran, 2016), while being supportive of the actions of Ukrainian propagandists, on the pretext that they are at the forefront of the fight against disinformation and propaganda coming from the Kremlin (Fitzpatrick, 2018: 45).

Meanwhile, Ukrainian media propagandists, in general, are far from providing objective information.

Let us examine a typical example of anti-Russian propaganda. In this case, it is an article by the Doctor of Sciences (in Philology), Professor V.V. Lizanchuk (in the Soviet era, a member of the Communist Party) - "Anti-Ukrainian information aggression in the television and radio space of Russia and Ukraine”. In our opinion, it is rather typical for the Ukrainian anti-Russian propagandists and contains practically all the standard building blocks/units of such media texts:

1) a unit of introduction to the problem, including clichéd propaganda phrases about Russian aggression and propaganda (including media sphere), about the need to emphasize the counterpropaganda function of the media (Lizanchuk, 2014: 13-16).

Below are just a few examples of V.V. Lizanchuk's anti-Russian (absolutely unsubstantiated) invectives: "Moscow's zoological hatred of everything Ukrainian, human, moral and spiritual has opened up to the world in a new way" (Lizanchuk, 2014: 15), "Putin's Russian leadership and the media, loyal to him, leave no chance for an average Russian to be a mentally healthy person, blocking all alternative sources of information" (Lizanchuk, 2014: 16).

The last phrase of V.V. Lizanchuk seems simply unprofessional for a Ph.D., Professor and Head of the department of broadcasting and television at university, because in the age of the Internet with its millions of open sources of information (in all world languages), it is ridiculous to argue that "alternative sources of information" are being cut off in Russia. Moreover, in fact, some Ukrainian journalists and political analysts appear live on leading Russian TV channels, and openly express their anti-Russian positions in discussions with their Russian counterparts.

Further on, V.V. Lizanchuk points out that "the Russian media totally deceive the citizens of their country, as well as shoots lies through the information space of Ukraine, poisoning the consciousness of Ukrainians, primarily the population of the eastern and southern regions. The trump card of Moscow's propaganda is Nazism, so-called Ukrainian fascism, "rabid bourgeois nationalism", and Bandera-ism" (Lizanchuk, 2014: 16). Notably, it is the above citation that demonstrates several of the common propaganda techniques: "demonizing the enemy", "dysphemism", and "false accusations". These techniques are highlighted by the careful choice of lexical means by the author: instead of neutral verbs, he deliberately uses the ones with negative connotation, those which cause fear, uncertainty, and anger: Russian media "deceive", "shoot lies", "poison".

True, the Russian media have always condemned and denounced Nazis' and Bandera's actions as crimes against humanity, as genocide. It is therefore surprising that V.V. Lizanchuk blames them for that.

Further on, V.V. Lizanchuk argues that the most striking aspect of Moscow's propaganda was and still is inspired by the events of Euromaidan in Kiev and "stories about fascists who, as they say, have taken over Kiev and want to ban everything Russian" (Lizanchuk, 2014: 16). Thus, V.V. Lizanchuk emphasized that such fears are groundless and false and are a product of Russian propaganda.

The real life history utterly refuted Lizanchuk's thesis: "democratic" Ukrainian authorities first cut off broadcasting of the leading Russian TV channels on Ukraine's territory and on 13.03.2020 President V. Zelensky signed the law "About complete general secondary education" which liquidated Russian-language schools in Ukraine and abolished programs of education in 
Russian (Law..., 2020), thereby depriving millions of citizens of this country to study in their native language since September 2020.

2) A unit of "appeal to authority" (a brief review of the literature on media, media manipulation, information wars, with an emphasis on the political stance of the European Union, the United States, etc.). Meanwhile, specifically phrases accusing or discrediting Russia are often selected from a wide range of academic literature (Lizanchuk, 2014: 17-19).

3) A unit of examples of Russian media propaganda (often from marginal sources and with selective-manipulative and emotional interpretation) (Lizanchuk, 2014: 18-19).

4) A unit of anti-Russian conclusions (Lizanchuk, 2014: 20-21).

In V.V. Lizanchuk's article, these conclusions are made with the framing technique of propaganda through language means. He also uses the propaganda technique called "transfer" or "association" (i.e. projecting negative qualities of a person, entity, object, or value onto another to discredit it), comparing Russian media to Goebbels' propaganda. V.V. Lyzanchuk argues, in particular, that "Ukraine is facing the most powerful Russian propaganda machine in the world, which also inherited all the infrastructure, technology, and know-how from the time of the Cold War between the USSR and the West. Open sources tell us that ten powerful media groups of the Russian Federation are working against Ukraine ... They have adopted the methods of Goebbels' propaganda. ... Goebbels once said that with media in his hands he can easily turn any nation into a herd of pigs. It seems that his recipes worked well, otherwise, how to explain such a high level of zombification of the majority of the population of Russia and some Ukrainian citizens in the Crimea, East and South of the country. Besides, Russia is used to living a lie" (Lizanchuk, 2014: 20).

The finale of V.V. Lizanchuk's article sounds especially aggressive and propagandistic, as it points out that "the most important task of Ukrainians now is to deprive themselves and future generations of many illusions of imaginary brotherhood, unity and friendship with the Russians, which is only possible on the basis of equality, mutual respect and freedom. Society should clean up our information space from Russian psychological interference and fake terror as persistently and purposefully as Ukrainian fighters clean up Putin's invaders and homegrown separatist terrorists in eastern Ukraine" (Lizanchuk, 2014: 20).

Another typical example of anti-Russian propaganda combined with media educational objectives is a textbook for Ukrainian teachers with the ambiguous title "NATO is a force that protects civilians" (Bakka et al., 2019). A big group of Ukrainian media educators participated in the creation of this manual.

An analysis of this textbook shows that, on the one hand, it is a kind of hymn praising the "most peace-loving" military alliance in the world (Bakka et al., 2019: 5-144), whose expansion to the east allegedly does not threaten Russia at all, while, on the other hand, it is a set of clichéd political accusations directed against Russia (Bakka et al., 2019: 145-158).

A vivid example of false information contained inside the educational material is the publication "First Lesson for Students in Grades 9-11. Ukraine starts with you" (Mitsay, Plyaka, 2019). The authors begin their recommendations for this patriotic lesson with the following key objectives:

- "assertion of national-patriotic self-awareness;

- deepening knowledge of the problem of patriotism as a social and personal value;

- definition of the qualities of a patriotic citizen;

- deepening of students' knowledge about the key events of the Ukrainian state in the twentieth century;

- acquaintance of students with the outstanding figures of social and political, military, cultural and artistic who made a significant contribution to the development of the Ukrainian state and the popularization of the national idea;

-promotion of understanding the common Ukrainian nation: state sovereignty, independence, territorial integrity and democratic principles of the state system;

- activation of students' cognitive interest in the historical and cultural heritage of the country and the state events of the history of Ukraine in the twentieth century;

- fostering respect for State symbols, and a respectful attitude to the traditions of Ukrainian and other ethnic groups living in the country;

- formation of an active life position of schoolchildren, their civic self-determination, social activity and desire for self-realization in Ukraine; 
- formation and development of motivation aimed at preparing to defend their homeland and serve in the Armed Forces of Ukraine" (Mitsay, Plyaka, 2019).

Yet, further in the text it is explained that Ukrainian "history and greatness have been created over the centuries by people whose names are carved in the heart of every Ukrainian", and there are the names of S. Bandera, A. Melnyk and R. Shukhevych (Mitsay, Plyaka, 2019), and among Ukraine's major historical dates is "the proclamation of the restoration of the Ukrainian State on June 30, 1941 in Lviv, occupied by German troops" (Mitsay, Plyaka, 2019).

Meanwhile, if one carefully reads the original text of the "Act of Proclamation of the Ukrainian State" (1941), one finds that in reality it in no way implied true Ukrainian independence, but rather stated that "the renewed Ukrainian State will cooperate closely with National Socialist Great Germany, which under Adolf Hitler creates a new order in Europe and the world and helps the Ukrainian people to free themselves from Moscow's occupation for a Sovereign Soborny Ukraina (Ukrainian State) and a new order in the whole world". So, if the authors of "The First Lesson for Students in Grades 9-11. Ukraine Starts with You" had dared to read the full text of this "Act..." to the Ukrainian students, they could have been convinced that the Ukrainian nationalists had wanted to live together with the Nazis under their laws and, therefore, to accept and welcome all their actions (such as the genocide of the Jews, keeping children and adult civilians of various nationalities in concentration camps of death, etc.).

Thus, under the guise of patriotic education, the authors of "The First Lesson for Students in Grades 9-11. Ukraine Starts with You", by manipulating with (another propaganda technique) "virtue words" of patriotism, independence, national identity, attempt to instill ideas to justify Nazism and its collaborators.

This kind of "patriotic media educational" material is by far not the only one in the information and communication space of Ukraine (see, for example: Bakka et al, 2016; Cherepovska, 2010; 2017; Collection..., 2015; 2017; 2020; Filonenko, 2020; Ivanov et al., 2016; Kharitonyuk, 2020; Koropatnyk, 2015; 2017; 2020; Lazorenko, 2020; Media..., 2021; Naidenova et al, 2018; Naidenova, Dyatel, 2020; Vlasyuk et al., 2019; Yuksel, 2020; Zental, 2020; Zorya et al., 2021, etc.).

Therefore it is critically important to be aware of frequent propaganda and disinformation techniques, such as labeling, "demonizing" a political enemy; appeal to authority, testimonial (the use of real and fictitious statements of persons with high authority for propaganda purposes); common man/plain folks (maximally simplifying information, attempting to convince the audience that the propagandist's positions reflect the common sense of the people); mosaic presentation of information (when, along with truthful information and theses, for example, the ideas of justifying Nazi criminals are introduced); blocking the critical and rational perception of the message by appealing to the simplest emotions, dysphemism (the choice of words with extreme negative connotation, such as "aggressor", "occupier", etc. in relation to another state); constant, obsessive repetition of certain statements, regardless of the truth; exploitation of slogans, myths and stereotypes (for example, glorifying figures unacceptable for a truly democratic society); the introduction of the necessary (false) information into, at first glance, neutral messages; unbalanced accentuation of only positive or only negative facts and arguments, while suppressing the opposite, etc.

\section{Results}

As a result of our research, we have developed and graphically presented (Figure 1) a theoretical media education model aimed at the effective development of the audience's skills to reasonably resist false (or partially false) information contained in anti-Russian Ukrainian Internet communication sources (taking into account the ability to analyze political, ideological , economic and other motives that determine anti-Russian propaganda in Ukrainian media educational Internet communication portals, websites), indicators, and ways of assessing the effectiveness of the above model.

The main building blocks/units of this model are as follows:

Unit 1. Technology for developing audience skills to rationally resist false (or partially false) information contained in anti-Russian Ukrainian Internet communication sources:

- awareness of the processes of media communications, propaganda influences and the typology of false (or partially false) information; 
- knowledge of the basic techniques for analyzing Internet communication sources (including fact checking; assessing political, ideological, economic and other motives that cause anti-Russian propaganda in Ukrainian (media education) Internet communication portals, websites;

- ability to apply this knowledge in the process of analyzing various Internet communication sources containing anti-Russian propaganda.

Unit 2. Anti-propaganda Internet communication competence of a person:

- information competence in the field of Internet communications and countering propaganda influences;

- analytical competence in the field of Internet communications of propagandistic and/or fake nature.

Unit 3. The main indicators of the anti-propaganda Internet communication competence of the individual:

- high level (comprehensive knowledge in the field of Internet communication, types and technologies of media influences, propaganda; types and technologies for analyzing media information);

- middle level (sufficient knowledge in the field of Internet communication, types and technologies of media influences, propaganda; types and technologies of media information analysis);

- low level (lack of knowledge (or minimal knowledge) in the field of Internet communication, types and technologies of media influences, propaganda; types and technologies for analyzing media information; lack of desire to analyze information).

Unit 4. Creative application of knowledge about the processes of media communications, propaganda influences and the typology of false (or partially false) information and analytical skills in this area:

- ability to independently apply knowledge about the processes of media communications, propaganda influences and the typology of false (or partially false) information and analytical skills in this area in new conditions and on new material.

\section{Conclusion}

Thus, the developed theoretical media education model, aimed at the effective progress of the audience's skills to reasonably oppose false (or partially false) information contained in antiRussian Ukrainian Internet communication sources (taking into account the ability to analyze political, ideological, economic and other motives that determine anti-Russian propaganda in Ukrainian media educational Internet communication portals, websites) consists of the following main structural units:

Unit 1. Technology for the development of audience skills is reasoned to resist false (or partially false) information contained in anti-Russian Ukrainian Internet communication sources (knowledge about media communication processes, propaganda influences and typology of false (or partially false) information; knowledge of the basic techniques of Internet analysis communication sources (including verification of facts, political, ideological, economic and other motives causing anti-Russian propaganda in Ukrainian (media education) Internet communication portals, websites; the ability to apply this knowledge in the process of analyzing various Internet communication sources containing anti-Russian propaganda.

Unit 2. Anti-propaganda Internet communication competence of a person (information competence in the field of Internet communications and countering propaganda influences; analytical competence in the field of propaganda and / or fake Internet messages).

Unit 3. The main indicators of anti-propaganda Internet communication competence of the individual (high level (a wide range of knowledge in the field of Internet communication, types and technologies of media influences, propaganda; types and technologies of media information analysis); medium level (limited knowledge in the field of Internet communication, types and technologies of media influences, propaganda; types and technologies of analysis of media information); low level (lack of knowledge (or minimal knowledge) in the field of Internet communication, types and technologies of media influences, propaganda; types and technologies of analysis of media information; lack of desire analyze information). 
Technology for developing audience skills to rationally resist false (or partially false) information contained in anti-Russian Ukrainian Internet communication sources

Awareness of the processes of media communications, propaganda influences and the typology of false (or partially false) information

Knowledge of the basic techniques for analyzing Internet communication sources (including fact checking; assessing political, ideological, economic and other motives that cause anti-Russian propaganda in Ukrainian (media education) Internet communication portals, websites

Ability to apply this knowledge in the process of analyzing various Internet communication sources containing anti-Russian propaganda

\section{Anti-propaganda Internet communication competence of a person}

Information competence in the field of Internet communications and countering propaganda influences

Analytical competence in the field of Internet communications of propagandistic and / or fake nature

\section{The main indicators of the anti-propaganda Internet communication} competence of the individual

high level (comprehensive knowledge in the field of Internet communication, types and technologies of media influences, propaganda; types and technologies for analyzing media information)

middle level (sufficient knowledge in the field of Internet communication, types and technologies of media influences, propaganda; types and technologies of media information analysis)

low level (lack of knowledge (or minimal knowledge) in the field of Internet communication, types and technologies of media influences, propaganda; types and technologies for analyzing media information; lack of desire to analyze information)

Creative application of knowledge about the processes of media communications, propaganda influences and the typology of false (or partially false) information and analytical skills in this area

Ability to independently apply knowledge about the processes of media communications, propaganda influences and the typology of false (or partially false) information and analytical skills in this area in new conditions and on new material

Fig. 1. Theoretical media education model aimed at the effective development of the audience's skills to reasonably resist false (or partially false) information contained in anti-Russian Ukrainian Internet communication sources 
Unit 4. Creative application of knowledge about the processes of media communications, propaganda influences and the typology of false (or partially false) information and analytical skills in this area (including the ability to independently apply knowledge about the processes of media communications, propaganda influences and the typology of false (or partially false) information and analytical skills in this area in new conditions and on new material).

\section{Acknowledgments}

The reported study was funded by RFBR and EISR, project number 21-011-31001.

\section{References}

Act..., 1941 - Akt progoloshennya Ukraïns'koï Derzhavi [Act of Proclamation of the Ukrainian State] (1941). Samostijna Ukraïna - Independent Ukraine. 10.07.1951: 1. [in Ukrainian]

Albright, 2017 - Albright, J. (2017). Welcome to the era of fake news. Media and Communication. 5(2): 87-89. doi: 10.17645/mac.v5i2.977

Aldwairi, Alwahedi, 2018 - Aldwairi, M., Alwahedi, A. (2018). Detecting fake news in social media networks. Procedia Computer Science. 141: 215-222.

Azzimonti, Fernandes, 2018 - Azzimonti, M., Fernandes, M. (2018). Social media networks, fake news, and polarization. NBER Working Paper. 24462: 1-64.

Bakir, McStay, 2018 - Bakir, V., McStay, A. (2018). Fake news and the economy of emotions: problems, causes, solutions. Digital Journalism. 6(2): 154-175. DOI: https://doi.org/10.1080/ 21670811.2017.1345645

Bakka et al., 2016 - Bakka, T., Burim, O., Voloshenuk, O., Yevtushenko, R., Meleshchenko, T., Mokroguz, O. (2016). Mediagramotnist' ta kritichne mislennya na urokakh suspil'stvoznavstva: posibnik dlya vchitelya [Media literacy and Critical Thinking at Social Science Lessons: a teacher's guide]. Kiev. [in Ukrainian]

Bakka et al., 2019 - Bakka, T., Volosheniuk, O., Zheliba, O., Yevtushenko, R., Meleshchenko, T., Malovany, O., Mokroguz, O. (2019). In: Voloshenuk, O., Dyomi, S. (eds.). NATO - cila, shcho zahishchae mirnih gromadyan. Posibnik dlya vikladacha ta vchitelya [NATO is a force that protects civilians. Teacher's and Teacher's Guide]. Kiev, 2019. [in Ukrainian]

Balmas, 2012 - Balmas, M. (2012). When fake news becomes real: combined exposure to multiple news sources and political attitudes of inefficacy, alienation, and cynicism. Communication Research. 20(10): 1-25. doi: 10.1177/0093650212453600

Bean, 2017 - Bean, J. (2017). The medium is the fake news. Interaction: 24-25. DOI: $10.1145 / 3064776$

Berghel, 2017 - Berghel, H. (2017). Lies, damn lies, and fake news. Computer: 80-85.

Bertin et al., 2018 - Bertin, B., Aguiar, L., Gomez-Herrera. E., Mueller-Langer, F. (2018). The Digital transformation of news media and the rise of disinformation and fake news. Seville: European Commission, Joint Research Centre. 56 p.

Bharali, Goswami, 2018 - Bharali, B., Goswami, A.L. (2018). Fake news: credibility, cultivation syndrome and the new age media. Media Watch. 9(1): 118-130. DOI: $10.15655 / \mathrm{mw} / 2018 / \mathrm{v} 911 / 49277$

Bradshaw, Howard, 2018 - Bradshaw, S., Howard, P.N. (2018). Challenging truth and trust: a global inventory of organized social media manipulation. Oxford: University of Oxford, $25 \mathrm{p}$.

Cherepovska, 2010 - Cherepovska, N.I. (2010). Mediakul'tura ta mediaosvita uchniv ZOSH: vizual'na mediakul'tura [Media culture and media education of secondary school students: visual media culture]. Kiev. [in Ukrainian]

Cherepovska, 2015 - Cherepovska, N.I. (2015). Mediaosvitni zasobi u vihovanni patriotizmu molodi $\mathrm{v}$ informacijnu dobu [Media educational tools in the education of youth patriotism in the information age]. Zbirnik stattej Tret'oü mizhnarodnoï naukovo-metodichnoï konferenciï "Praktichna mediagramotnist': mizhnarodnij dosvid ta ukraïns'ki perspektivi". Kiev. [in Ukrainian]

Cherepovska, 2017 - Cherepovska, N.I. (2017). Mediaosvitni resursi rozvitku patriotizmu i kritichnogo mislennya molodi: navchal'no-metodichnij posibnik [Media educational resources for the development of patriotism and critical thinking of youth: a textbook. National Academy of Pedagogical Sciences of Ukraine, Institute of Social and Political Psychology]. Kropyvnytsky. [in Ukrainian] 
Collection..., 2015 - Zbirnik stattej Tret'oï mizhnarodnoï naukovo-metodichnoï konferenciï "Praktichna mediagramotnist': mizhnarodnij dosvid ta ukraïns'ki perspektivi" (2015) [Collection of articles of the Third International Scientific and Methodological Conference "Practical Media Literacy: International Experience and Ukrainian Perspectives". Kiev. [in Ukrainian]

Collection..., 2017 - Zbirnik statej P’yatoï mizhnarodnoï naukovo-metodichnoï konferenciï "Praktichna mediagramotnist': mizhnarodnij dosvid ta ukraïns'ki perspektivi" (2017) [Collection of articles of the Fifth International Scientific and Methodological Conference "Practical Media Literacy: International Experience and Ukrainian Perspectives". Kiev. [in Ukrainian]

Collection..., 2020 - Zbirnik statej Vos'moï mizhnarodnoï naukovo-metodichnoï konferenciï "Kritichne mislennya v epohu toksichnogo kontentu" (2020) [Collection of articles of the Eighth International Scientific and Methodological Conference "Critical Thinking in the Age of Toxic Content"]. Kiev. [in Ukrainian]

Conroy et al., 2015 - Conroy, N.J., Rubin, V.L., Chen, Y. (2015). Automatic deception detection: methods for finding fake news. ASIST 2015. St. Louis, USA.

Dentith, 2017 - Dentith, M.R.X. (2017). The Problem of fake news. Public Reason. 8(1-2): 65-79.

Derakhshan Wardle, 2017 - Derakhshan H., Wardle, C. (2017). Information disorder: definitions. understanding and addressing the disinformation ecosystem. Annenberg School for Communication: 5-12.

Farkas, Schou, 2018 - Farkas, J., Schou, J. (2018). Fake news as a floating signifier: hegemony, antagonism and the politics of falsehood. Javnost. 25(3): 298-314. DOI: 10.1080/13183222.2018.1463047

Fedorov, Levitskaya, 2021 - Fedorov, A., Levitskaya, A. (2021). Theoretical model and technology of anti-Russian propaganda in Internet communications of modern Ukraine within the framework of various student groups' media education. Media education. 17(3): 443-451. DOI: $10.13187 / \mathrm{me} .2021 .3 .443$

Figueira, Oliveira, 2017 - Figueira, A. Oliveira, L. (2017). The current state of fake news: challenges and opportunities. Procedia Computer Science. 121: 817-825.

Filonenko, 2020 - Filonenko, V.V. (2020). Visvitlennya temi rosijs'ko-ukraïns'koï vijni v umovah pandemiï [ Coverage of the Russian-Ukrainian war in a pandemic] Naidenova, L.A., Dyatel, N.L. (eds.) (2020). Kibersocializaciya. Kropyvnytsky. [in Ukrainian]

Fitzpatrick, 2018 - Fitzpatrick, N. (2018). Media manipulation 2.0: the impact of social media on news, competition, and accuracy. Athens Journal of Mass Media and Communications. 4(1): 45-62. DOI: 10.30958/ajmmc.4.1.3

Fletcher et al., 2018 - Fletcher, R., Cornia, A., Graves, L., Nielsen, R.K. (2018). Measuring the reach of "fake news" and online disinformation in Europe. Oxford: University of Oxford: 1-10.

Fletcher, Nielsen, 2017 - Fletcher, R., Nielsen, R. (2017). People don't trust news media and this is key to the global misinformation debate. Understanding and Addressing the Disinformation Ecosystem. Los Angeles: Annenberg School for Communication: 13-17.

Gahirwal et al., 2018 - Gahirwal, M., Moghe, S., Kulkarni, T., Khakhar, D., Bhatia, J. (2018). Fake news detection. International Journal of Advance Research, Ideas and Innovations in Technology. 4(1): 817-819.

Giles, 2016 - Giles, K. (2016). Handbook of Russian Information Warfare. Rome: NATO Defense College, 2016, $77 \mathrm{p}$.

Goering, Thomas, 2018 - Goering, C.Z., Thomas, P.L. (eds.) (2018). Critical media literacy and fake news in post-truth America. Leiden: Brill Sense.

Ivanov et al., 2016 - Ivanov, V., Voloshenuk, O., Mokroguz, O. (eds.). Mediagramotnist' na urokah suspil'nih disciplin: Posibnik dlya vchitelya [Media literacy in the lessons of social disciplines: A guide for teachers]. Kiev. [in Ukrainian]

Janze, Risius, 2017 - Janze, C., Risius, M. (2017). Automatic detection of fake news on social media platforms. PACIS 2017 Proceedings. [Electronic resource]. URL: http://aisel.aisnet.org/ pacis2017/261

Khaldarova, Pantti, 2016 - Khaldarova, I, Pantti, M. (2016). Fake news: The narrative battle over the Ukrainian conflict. Journalism Practice. 10 (7): 891-901. DOI: https://doi.org/10.1080/ 17512786.2016.1163237

Kharitonyuk, 2020 - Kharitonyuk, O. (2020). Zbroya xxi stolittya - ne zbroya!? [Weapons of the XXI century are not weapons!?]. Zbirnik statej Vos'moï mizhnarodnoï naukovo-metodichnoï konferencï "Kritichne mislennya $v$ epohu toksichnogo kontentu”. Kiev. [in Ukrainian] 
Koropatnyk, 2015 - Koropatnyk, M. (2015). Osoblivosti mediaosviti v umovah "gibridnoï vijni” Rosiï proti Ukraïni [Peculiarities of media education in the conditions of "hybrid war" of Russia against Ukraine]. Zbirnik stattej Tret'oï mizhnarodnoï naukovo-metodichnoï konferenciï "Praktichna mediagramotnist': mizhnarodnij dosvid ta ukraïns'ki perspektivi". Kiev. [in Ukrainian]

Koropatnyk, 2017 - Koropatnyk, M. (2017). Problemi formuvannya mediaobiznanosti naselennya ukraïni shchodo podij v Krimu i na Donbasi v konteksti informacijno-propagandists'koï agresiï Rosiï [Problems of formation of media awareness of the population of Ukraine on the events in Crimea and Donbas in the context of information and propaganda aggression of Russia]. Zbirnik statej P'yatoï mizhnarodnoï naukovo-metodichnoï konferencï "Praktichna mediagramotnist': mizhnarodnij dosvid ta ukraïns'ki perspektivi”. Kiev. [in Ukrainian]

Koropatnyk, 2020 - Koropatnyk, M. (2020). Nova ukraïns'ka shkola: chi potribna pedagogam ta uchnyam informacijno-komunikacijna kompetentnis'? [The New Ukrainian school: do teachers and students need information and communication competence?]. Zbirnik statej Vos'moï mizhnarodnoï naukovo-metodichnoï konferencï "Kritichne mislennya v epohu toksichnogo kontentu". Kiev. [in Ukrainian]

Law..., 2020 - Zakon Ukraïni "Pro povnu zagal'nu serednyu osvitu". Verhovna Rada Ukraïni (2020). [Law of Ukraine "On Complete General Secondary Education". Verkhovna Rada of Ukraine]. [in Ukrainian] [Electronic resource]. URL: https://xn--8oaagahqwyibe8an.com/ukrajiny-zakony/ zakon-ukrajini-pro-povnu-zagalnu-serednyu-2020-80785.html

Lazorenko, 2020 - Lazorenko, B.P. (2020). Reintegraciya osobistosti v umovah gibridnih vijni ta miru: social'no-psihologichni mekhanizmi vidchuzhennya ta prisvoennya sub'ektnosti [Reintegration of the individual in the conditions of hybrid war and peace: socio-psychological mechanisms of alienation and appropriation of subjectivity]. In Naidenova, L.A., Dyatel, N.L. (eds.). Kibersocializaciya. Kropyvnytsky. [in Ukrainian]

Levitskaya, Fedorov, 2021 - Levitskaya A., Fedorov A. Theoretical model of media competence's development of teachers-to-be in the process of the analysis of manipulative media influences. Media Education. 17(2): 323-332. DOI: 10.13187/me.2021.1.323

Lipman, 2009 - Lipman, M. (2009). Media manipulation and political control in Russia. London: Chatham House: 1-16.

Lizanchuk, 2014 - Lizanchuk, V.V. (2014). Antiukraïns'ka informacijna agresiya v teleradioprostori Rosiï ta Ukraïni [Anti-Ukrainian information aggression in the TV and radio space of Russia and Ukraine]. In: Rizun, V.V. (ed.). Naukovi zapiski Institutu zhurnalistiki. Kiev: 13-21. [in Ukrainian]

Marwick, 2018 - Marwick, A.E. (2018). Why do people share fake news? A sociotechnical model of media effects. Georgetown law technology review. 2(2): 474-512.

Marwick, Lewis, 2017 - Marwick. A., Lewis, R. (2017). Media manipulation and disinformation online. New York: Data \& Society Research Institute. 104 p.

Media..., 2021 - Mediapsihologiya ta mediaosvita (2021). [Media Psychology and Media Education]. Mediaosvita - Media Education. [Electronic resource]. URL: http://mediaosvita. org.ua/pro-nas/

Mihailidis, Viotty, 2017 - Mihailidis, P., Viotty, S. (2017). Spreadable spectacle in digital culture: civic expression, fake news, and the role of media literacies in "post-fact" society. American Behavioral Scientist: 1-14. DOI: 10.1177/0002764217701217

Mitsay, Plyaka, 2019 - Mitsay, Y.V., Plyaka, S.M. (2019). Pershij urok dlya uchniv 9-11 klasiv. Ukraïna pochina€t'sya $\mathrm{z}$ tebe [The first lesson for students in grades 9-11. Ukraine starts with you]. 23.07.2019. [in Ukrainian] [Electronic resource]. URL: https://erudyt.net/vixovnizaxodi/konspekti-do-1-veresnya/pershyj-urok-dlya-uchniv-9-11-klasiv-ukrajina-pochynajetsya-ztebe.html

Murrok et al., 2018 - Murrock, E., Amulya, J., Druckman, M., Liubyva, T. (2018). International Winning the war on state-sponsored propaganda gains in the ability to detect disinformation a year and a half after completing a Ukrainian news media literacy program. Washington: Research and Exchanges Board (IREX), 47 p.

Naidenova et al., 2018 - Naidenova, L.A., Cherepovska, N.I., Voznesenskaya, O.L., Chaplinskaya, Y.S., Obukhova, N.O., Dyatel, N.L., Bondarevskaya, I.O., Kryshovska, O.O. (2018). Mediakul'tura. Navchal'na programa dlya uchniv 9, 10, 11 klasiv zakladiv zagal'noï seredn'oï osviti 
(tri roki navchannya) [ Media culture. Curriculum for students of 9th, 10th, 11th grades of general secondary education (three years of study)]. Kiev. [in Ukrainian]

Naidenova, Dyatel, 2020 - Naidenova, L.A., Dyatel, N.L. (eds.) (2020). Kibersocializaciya [Cyber Socialization]. Kropyvnytsky. [in Ukrainian]

NATO, 2016 - NATO (2016). Internet trolling as a tool of hybrid warfare: the case of Latvia, 106 p. [Electronic resource]. URL: http://www.stratcomcoe.org/internet-trolling-hybrid-warfaretool-case-latvia-o

Pocheptsov, 2015 - Pocheptsov, G.G. (2015). Propaganda 2.0: Novye izmereniya v dejstvii [Advocacy 2.0: New Dimensions in Action]. 5.07.2015. [in Russian] [Electronic resource]. URL: http://ms.detector.media/trends/1411978127/propaganda_20_novye_izmereniya_v_deystvii/

Pocheptsov, 2016 - Pocheptsov, G.G. (2016). Smisli i vijni: Ukraïna i Rosiya v informacijnij i smislovij vijnah [Meanings and wars: Ukraine and Russia in information and semantic wars]. Kiev. [in Ukrainian]

Pocheptsov, 2017 - Pocheptsov, G.G. (2017). Glavnyj ob"ekt ataki dlya Rossii mezhdunarodnoe soobshchestvo i sobstvennoe naselenie... The main object of attack for Russia is the international community and its own population...] [in Russian] [Electronic resource]. URL: http://politdengi.com.ua/novosti-ukraini/kiev/110385.html

Ruchansky et al., 2017 - Ruchansky, N., Seo, S., Liu, Y. (2017). CSI: A hybrid deep model for fake news detection. CIKM'17. DOI: 10.1145/3132847.3132877

Saran, 2016 - Saran, V. (2016). Media manipulation and psychological war in Ukraine and the Republic of Moldova, CES Working Papers. 8(4): 738-752.

Vargo, 2018 - Vargo, C.J. (2018). The agenda-setting power of fake news: A big data analysis of the online media landscape from 2014 to 2016. New Media \& Society. 20(5): 2028-2049. DOI: $10.1177 / 1461444817712086$

Vlasyuk et al., 2019 - Vlasyuk, O.V., Ivanova, T.V., Sribna, I.S., Potapova, V.I. (2019). Praktichna mediagramotnist' dlya bibliotek [Practical media literacy for libraries]. Kiev. [in Ukrainian]

Waldrop, 2017 - Waldrop, M.M. (2017). The genuine problem of fake news. PNAS. 114(48): 12631-12634. DOI: 10.1073/pnas.1719005114

Yuksel, 2020 - Yuksel, G.Z. (2020). Social'ni merezhi yak zasib protidiï rozpovsyudzhennyu pandemiï covid-19 v umovah timchasovoï okupaciï Krimu [Social networks as a means of counteracting the spread of the covid-19 pandemic in the conditions of temporary occupation of Crimea]. Naidenova, L.A., Dyatel, N.L. (eds.) (2021). Kibersocializaciya. Kropyvnytsky. [in Ukrainian]

Zental, 2020 - Zental, O.Y. (2020). Informacijna bezpeka pid chas gibridnoï vijni proti Ukraïni [Information security during the hybrid war against Ukraine]. In Naidenova, L.A., Dyatel, N.L. (eds.). Kibersocializaciya. Kropyvnytsky: 50-51. [in Ukrainian]

Zorya et al., 2021 - Zorya, Y.M., Stepanova, N.M., Potapova, V.I. (2021). Mediagramotnist' dlya bibliotekariv: praktichnij posibnik [Media literacy for librarians: a practical guide]. Kiev. [in Ukrainian] 